\title{
First report of Pepper mottle virus in Iran
}

\author{
Mohadese Gerami Nooghabi ${ }^{1}$ (I)
}

Received: 29 September 2021 / Accepted: 17 February 2022 / Published online: 1 March 2022

(c) The Author(s) under exclusive licence to Australasian Plant Pathology Society Inc. 2022

\begin{abstract}
Pepper mottle virus is a member of genus Potyvirus and infects many plants worldwide. Bell pepper (Capsicum annuum) leaves with virus symptoms were collected, and after using RT-PCR amplification using pepper mottle virus-specific primers for the coat protein, amplicons were sequenced. Sequences revealed the presence of pepper mottle virus (PeMV) for the first time in Iran. Phylogenetic analysis of the coat protein sequences showed that Iranian isolates shared greatest pairwise identities (98.6\%) with those from Korea, and lowest identities (91.5\%) with those from Cuba.
\end{abstract}

Keywords Pepper mottle virus $\cdot$ Iran · Coat Protein and phylogenetic analysis

Pepper mottle virus (PeMV) is a positive-sense single stranded RNA virus that belongs to the Potyvirus genus (Kim et al. 2009). PeMV was first identified from Capsicum annuum in Arizona, USA, in 1960 as a novel Potyvirus (Nelson and Wheeler 1972). In 1972, Zitter described this virus from Capsicum annuum in Florida (USA) (Zitter 1972). And afterward, PeMV has been detected from different countries such as Japan (Ogawa et al. 2003), Korea (Kim et al. 2009), Cuba (Quiñones et al. 2011), Taiwan (Cheng et al. 2011), India (Kaur et al. 2014),, nigeria (Olawale et al. 2015) and China (Sharma et al. 2018).

In 2020, leaves from field pepper (California wonder variety) with dark green mosaic, distortion and yellowing symptoms were collected from eastern areas of Iran (Gonabad, Razavi Khorasan Province). To confirm virus infection, total RNA was extracted using RNeasy Mini Kit (Qiagen, Germany) and used as a template for reverse transcription polymerase chain reaction (RT-PCR (Pars toos Reverse transcriptase (Iran) Cat. No. 9003610000 and Red Ampliqon PCR mix, Kit Cat. No. A190399)) performed using specific primer pairs designed based on the coat protein (CP) gene of Korea isolates (Forward: 5'-AAACCAAGCCAAGTTGAC AT-3' and Reverse: 5'-CTTGTGTTCCTATGCCACCG-3') (Kim et al. 2009).in one of the 26 C.аnnиum plants sampled, the expected 500 bp DNA fragment, was amplified

Mohadese Gerami Nooghabi

Mohadese.gerami@yahoo.com

1 Department of Agricultural and Natural Resources, University of Gonabad, Gonabad, Iran and sequenced directly. This sample showed mosaic and malformation symptoms in upper leaves (Fig. 1). Sequence of PeMV-Iran was deposited in GenBank (PeMV-Iran: MZ288736) after verify in BLAST program (https://blast. ncbi.nlm.nih.gov). In comparison to other isolates from the world, the CP gene sequences of PeMV-Iran isolate showed the highest nucleotide and amino acid identity (98.62\% and 99.96\%, respectively) with isolate from Korea (EU586133) and low level nucleotide identities (91.54\%) with Cuba isolate (JN222367) and in amino acid level (99.88\%) with China isolate (KX446789).

Maximum likelihood Phylogenetic analysis of the CP gene amino acid sequence in MEGA X (Kumar et al. 2018) reveals that PeMV isolates can be clustered to three distinct

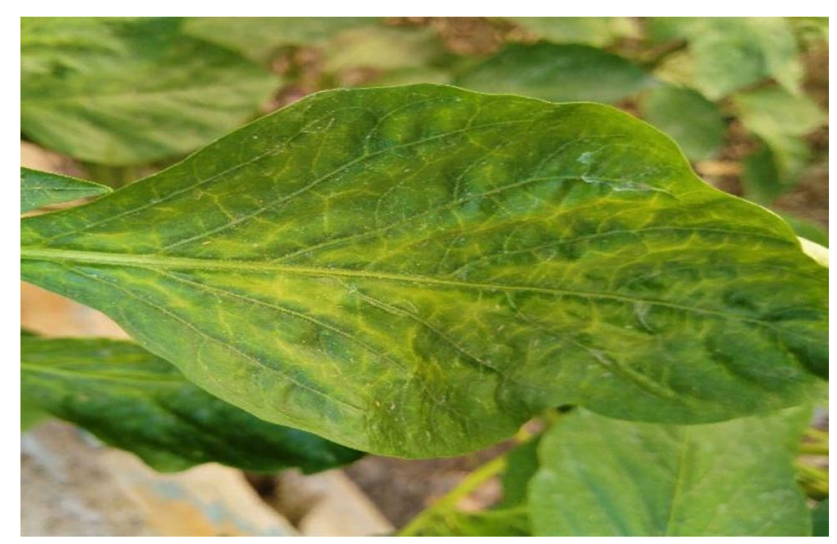

Fig. 1 Mosaic and distortion symptoms in a pepper mottle virus affected Capsicum annuum leaf 
Fig. 2 Maximum likelihood tree calculated from the coat protein amino acids sequences of Iranian pepper mottle virus with the other 29 isolates from worldwide. Isolates are indicated in the tree by accession number and geographical origin of collection. Multiple sequence alignments were generated by Clustel $\mathrm{W}$ assembled in the MEGA $\mathrm{X}$ package. Numbers at each node indicate bootstrap percentages based on 1000 replications. The nucleotide sequence of a potato virus V (KY711358) isolate was used as outgroup (Warren and Murphy 2003)

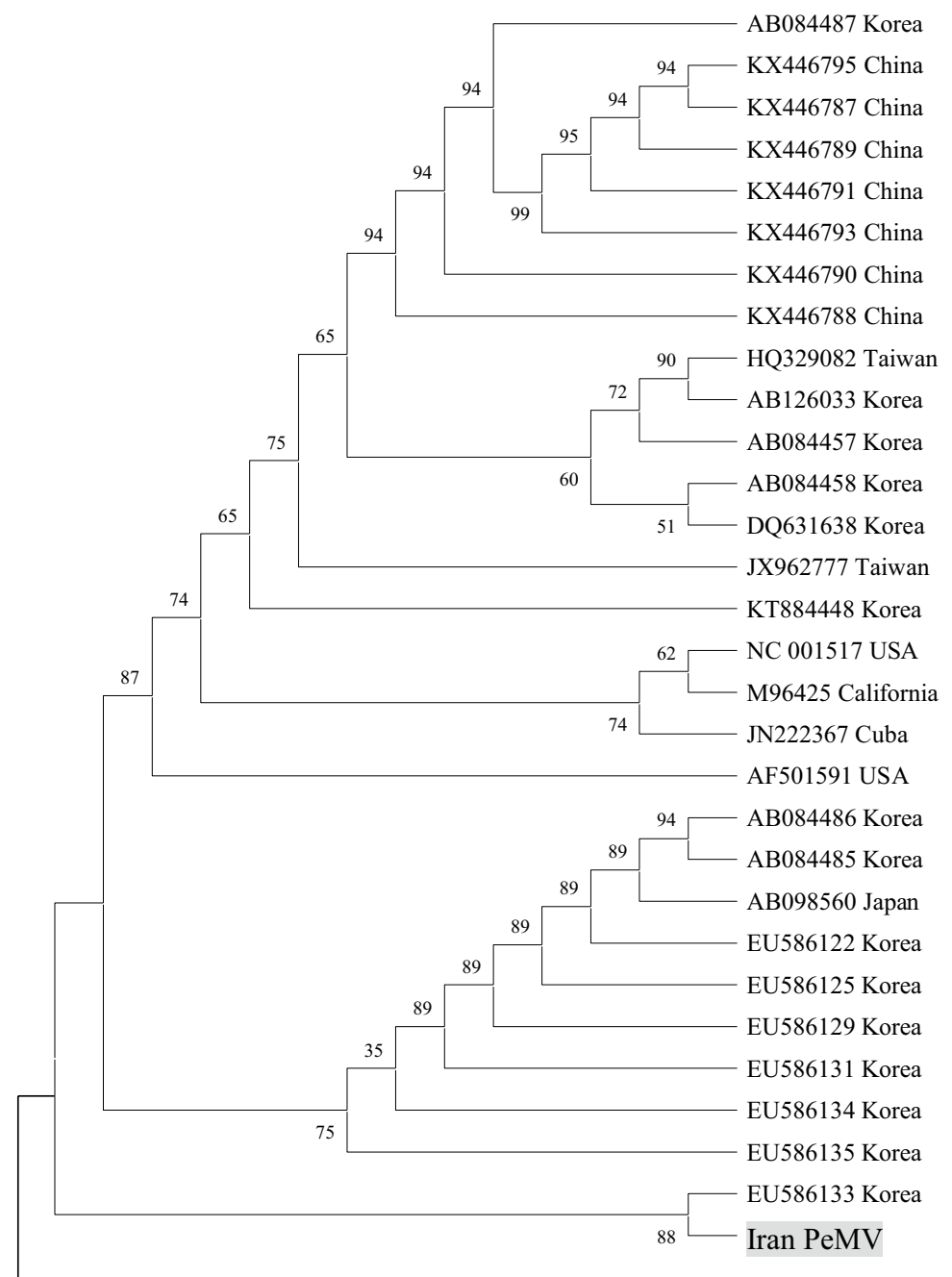

KY711358 PVV groups and Iranian PeMV isolate located alongside by a South Korea (EU586133) in one group (Fig. 2). According to the phylogenetic tree, it can be concluded that the geographical area is not the only factor in the grouping of isolates and similar other Potyviruses, further influences are effective in the phylogenetic classification of this virus (Chen et al. 2001).

In Iran, no molecular investigation of PeMV was reported. Since the pepper is one of the main vegetables in Iran (Aminifard and Bayat 2018), so this study is a beneficial report of the existence of a new limiting factor for the production of this crop. To our knowledge this is the first report of pepper mottle virus from Iran.

More than 40 plant viruses, can infect peppers (Kim et al. 2009) and viral diseases are drastic cause in reducing the pepper production (Arogundade et al. 2012), therefore increasing our knowledge of pepper viruses will be effective to improve management of these diseases in field.

\section{Declarations}

Conflict of interests The authors declare that they have no conflict of interest.

\section{References}

Aminifard MH, Bayat H (2018) Influence of different rates of nitrogen fertilizer on growth, yield and fruit quality of sweet pepper (Capsicum annum L. var. California Wander). J Horticulture And Postharvest Res 1(2):105-114. https://doi.org/10.22077/jhpr.2018. $1423 / 1013$

Arogundade O, Balogun OS, Kareem KT (2012) Occurrence and distribution of pepper veinal mottle virus and cucumber mosaic virus in pepper in Ibadan, Nigeria. Virology Journal 9:79-82. https:// doi.org/10.1186/1743-422X-9-79

Chen J, Chen J, Chen J, Adams MJ (2001) Molecular characterization of an isolate of Dasheen mosaic virus from Zantedeschia aethiopica in China and comparisons in the genus Potyvirus. Archive of Virology 146:1821-1829. https://doi.org/10.1007/s0070501170068 
Cheng YH, Deng TC, Chen CC, Liao JY (2011) First report of Pepper mottle virus in Bell pepper in Taiwan. Plant Dis 95(5):617. https:// doi.org/10.1094/PDIS-10-10-0721

Kaur S, Kang SS, Sharma A, Sharma S (2014) First report of Pepper mottle virus infecting chilli pepper in India. New Disease Reports 30:14. https://doi.org/10.5197/j.2044-0588.2014.030.014

Kim YJ, Jonson MG, Choi HS, Ko SJ, Kim KH (2009) Molecular characterization of Korean Pepper mottle virus isolates and its relationship to symptom variations. Virus Res 144(1-2):83-88. https://doi.org/10.1016/j.virusres.2009.04.003

Kumar S, Stecher G, Li M, Knyaz C, Tamura K (2018) Mega X: molecular evolutionary genetics analysis across computing plattforms. Mol Biol Evolution 36(5):1547-1549

Nelson MR, Wheeler RE (1972) Biological and Serological Characterization and Separation of Potyviruses that Infect Peppers. Phytopathology 68:979-984

Ogawa Y, Hagiwara K, Iwai H, Izumi S, Arai K (2003) First report of pepper mottle virus on Capcicum annuum in Japan. J Gen Plant Pathol 69:348-350. https://doi.org/10.1007/s10327-003-0059-6
Olawale A, Samuel BO, Solomon AS, Kumar PL (2015) Surveys of virus diseases on pepper (Capsicum spp.)in south-west Nigeria. Afr j Biotechnol 14(48):3198-3205. https://doi.org/10.5897/ AJB2015.14803

Quiñones M, Arana F, Alfenas-Zerbini P, Soto M, Ribeiro D, Diaz A, González D, Carbonell J, Depestre T, Zerbini FM (2011) First report of Pepper mottle virus in sweet pepper in Cuba. New Disease Reports 24:16. https://doi.org/10.5197/j.2044-0588.2011. 024.016

Sharma Sh, Kang SS, Sharma A (2018) Seed transmissibility of Pepper mottle virus: survival of virus. Curr Sci 115(11):2012-2014. https://doi.org/10.1007/s13337-019-00543-4

Warren CE, Murphy JF (2003) The complete nucleotide sequence of Pepper mottle virus-Florida RNA. Archive of Virology 148:189197. https://doi.org/10.1007/s00705-002-0915-2

Zitter TA (1972) Naturally occurring pepper virus strains in south Florida. Plant Disease Reporter 56:586-590 